\title{
China's technological performance as reflected in patents
}

\author{
Ulrich Schmoch ${ }^{1}$ (D) $\cdot$ Birgit Gehrke ${ }^{2}$
}

Received: 3 February 2021 / Accepted: 20 October 2021 / Published online: 8 November 2021

(c) The Author(s) 2021

\begin{abstract}
Various concepts for the comparison of countries by patent indicators have been developed for the comparison of countries based on patent indicators. These concepts are generally based on the application of patents in several important markets or the family size of patent applications. A specific observation is the limited transfer of PCT applications of Chinese origin, affecting all these concepts. Transnational patents prove to be a convenient and appropriate tool for making country comparisons by technology, particularly with respect to adequately consider China's specific patent behaviour. Therefore the phenomenon of limited transfer of China's PCT applications is analysed for transnational patents. This observation can be associated with lower patent values or with a decreasing export dynamic. The Chinese transfer rates vary considerably by technology as well as by the reason for lower transfer rates. It proves to be more adequate to take limited transfer rates into account.
\end{abstract}

Keywords Transnational patents · Low transfer rates of China - Lower patent value Decreasing export dynamics

\section{Introduction}

How to compare countries using patent statistics has been discussed for more than 30 years (e.g. Griliches, 1990; Hinze \& Schmoch, 2004; Pavitt, 1985; Schmoch \& Khan, 2019; Schmoch et al., 1988). The basic problem is that the comparison of patent applications from different countries without any specification factually implies the comparison of domestic patent applications from different patent systems which leads to a substantial overestimation of the Southeast Asian countries China, South Korea and Japan. Various concepts of country comparisons were developed. These concepts generally are based on

Ulrich Schmoch

us@isi.fhg.de

Birgit Gehrke

gehrke@cws.uni-hannover.de

1 Ulrich Schmoch, Fraunhofer ISI, Karlsruhe, Germany

2 Center for Economic Policy Studies, Institute of Economic Policy, Leibniz University Hannover, Hannover, Germany 
the family size of patent applications. The meaning of family size is explained in more detail in chapter 2.1 .

However, a recent publication by Frietsch and Kroll (2020) shows that Chinese PCT applications, applications according to the Patent Cooperation Treaty, are transferred to national offices distinctly less often than the PCT applications of other countries. The use of PCT applications is explained further below in chapter 3.3.This observation challenges the concepts of country comparisons linked to family size, as the family size signalled by a PCT applications in the early stage of applications is not put into effect later on. Against this background, we examine in more detail whether the concepts of country comparison are still valid with regard to China or whether they have to be modified. In particular, we will consider the concept of transnational patents in more detail.

In chapter 2, various concepts of country comparison are briefly introduced and discussed with regard to possible effects of the reduced PCT transfer of China. In chapter 3, the concept of transnational patents is presented as example in more detail for an improved understanding which elements are affected by China's reduced PCT transfer. In chapter 4, the consequences of China's reduced PCT transfer on country comparisons are demonstrated. In chapter 5, the assessment of the value of China's patents is examined by a literature analysis and statistical analyses. For an improved understanding of China's reduced PCT transfer, chapter 6 describes the economic orientation of China between export and domestic growth.

To answer the question whether the standard concept of transnational patents or a concept with consideration of the reduced PCT transfer is more appropriate, the relation between patents and business expenditures on research and development (BERD) is analysed in chapter 7, but with limited insight for the question of appropriateness. Only the need of finer differentiation for describing the effects of reduced PCT transfer gets obvious. Therefore, a differentiation of patents by technology and a link to export specialisation is made in chapter 8 leading to meaningful results. Chapter 9 concludes.

\section{Concepts of country comparison}

As the comparison of the technological performance of countries is a major target of patent analysis, various concepts were suggested for achieving appropriate results. The most considered concepts are.

- International patent families, patent families with at least two members

- Triadic Patents

- The IP5 concept

- The concept of worldwide counts

- Transnational Patents

\section{International patent families}

A frequently made proposal for country comparisons is to use applications in foreign countries, as these applications imply much higher costs of application than domestic applications hence capturing the most valuable inventions. Formally this means that only patent families with at least two members are counted, that is patent families with a domestic application and at least one application in a foreign country. The drawback of this approach 
is that-due to the specific geopolitical situation - the propensity to patent in foreign countries differs between countries of origin. For instance, the step from the Netherlands to Germany implies a family size of two members, as does the step from China to the US. The concept of international patent families is used, for instance, by the World Intellectual Property Organisation (WIPO) in its annual World Intellectual Property Reports (see, e.g., WIPO, 2019: 123). In specific analyses for technologies, the patent numbers of Japan appear to be overestimated (Schmoch \& Khan, 2019: 916).

The model is influenced by the limited PCT transfer of China, as it is possible that a family with seemingly two members at the stage of applications is reduced to one member later on.

\section{Triadic patents}

An early suggestion for appropriate country comparisons were so-called triadic patents (Grupp et al., 1996), which focus on applications filed in the USA-Europe-Japan triad. This approach was taken over by the OECD and used for many years. But, it became increasingly obsolete in the late 1990ies, as the economic power of China and South Korea grew. A possible alternative would be a new triad with USA-Europe-Southeast Asia, with Japan, China and South Korea combined.

The concept is also affected by the limited PCT transfer of China, as initially triadic patents can disappear later on, when e.g. a PCT application with the designated country US is not transferred to the US.

\section{The IP5 concept}

The IP5 concept was suggested by the OECD. There, patent applications to the five major patent offices in the world are considered: the EPO, the USPTO, the JPO, the SIPO, and the KIPO (OECD, 2015: 20).

The most restrictive definition is that families of patent applications are considered only in so far as family members have been filed with at least two IP5 offices. For instance, patents filed with the USPTO will be considered only if an equivalent filing has been made with at least one of the remaining four IP5 offices. This is irrespective of whether equivalent applications in non-IP5 offices also exist. (OECD, 2015: 20f).

It is possible that the threshold for Southeast Asian countries is quite low, as e.g., the step from China to Japan is smaller than that from Europe to the US. In consequence, these countries are overestimated in analyses for specific technology (Schmoch \& Khan, 2019: 916).

The limited transfer of PCT patents of China can imply that one IP5 of the two necessary offices disappears later on.

\section{Worldwide patent counts}

This concept was suggested by the OECD and some universities (De Rassenfosse et al., 2013). The indicator of worldwide patent counts "is based on counting all the priority applications filed by a country's inventors regardless of the patent office in which the application is filed (Ibid. 720). Thus, the focus is on domestic patents. For coping with the 
distortion of country comparisons by domestic patents, the authors suggest to eliminate the "institutional bias", i.e. the differences between the national patent systems, by the introduction of patent families, thus the introduction of patent values, the use of transfer rates between patent offices, raising the question of an appropriate reference office, or by a normalisation of the patent counts by national data for the Gross Expenditures non Research and Development (GERD). This appears to be useful, but the use of business expenditures on R\&D (BERD) might be more appropriate, as most patents are applied by enterprises. Furthermore the normalisation by GERD or BERD is problematic, as the responsiveness to R\&D input considerably differs by countries (Cerulli, 2014), in particular the relation to patents. As the focus is on domestic patents, the limited transfer of Chinese PCT patents has no effect on the indicator. However, the question remains whether the exclusion of patent values is useful for country comparisons.

The practical use of worldwide patent counts is quite intricate and laborious, as reference list of annual R\&D statistics or transfer rates have to be established and linked to the patent data. Furthermore, the concept is conceived for the database PATSTAT. But for emerging technologies, no codes of the International Patent Classification (IPC) often exist, yet. Therefore, it is necessary to apply keywords for searches, but keyword searches in PATSTAT are lengthy and ineffective (Schmoch \& Khan, 2019:917).

In view of the shortcomings of the different approaches, the concept of transnational patents proves to be the most appropriate and useful one. This is shown by Schmoch and Khan (2019: 914ff.) by systematically comparing the appropriateness of different concepts of country comparisons for the analysis of technical fields. For example, by transnational patents, similar results for the case of wind-power shown by De Rassenfosse et al., (2013:728ff.) are achieved, but with much less time and effort. The concept of transnational patents proved to provide meaningful results for many technologies such as mechanical technologies, information technology, biotechnology etc. where the information on enterprises, sales, exports, R\&D etc. were consistent with the patent data (see e.g. Döscher \& Reiss, 2021 or Beckert et al., 2016).

Transnational patents can be analysed in PATSTAT, in the case of keyword-based searches also in databases like the World Patents Index (WPI).

All concepts of country comparison discussed above aim at the international comparison of the technological competitiveness of advanced countries. For other goals such as the analysis of inventiveness of developing countries or narrow technological fields, a broader capture of small and medium-sized enterprises or the compilation of regional pattern the use of domestic applications may be more appropriate (Haščič et al., 2015). In this context, a finer differentiation of domestic patents by value is even possible (Dechezleprêtre et al., 2017).

In the following chapters, the effect of the reduced transfer of Chinese PCT applications will be analysed for transnational patents in more detail as example for concepts of International comparisons of countries.

\section{The concept of transnational patents}

The concept of transnational patents is based on the frequent finding that the family size of patent applications is the strongest indicator of patent value (see, e.g. Harhoff et al., 2003). Transnational patents are either applications at the European Patent Office (EPO) or international applications at the World Intellectual Property Office (WIPO) according to 
the Patent Cooperation Treaty (PCT), so-called PCT applications (Frietsch and Schmoch 2010). Both EPO and WIPO applications imply multiple further applications at foreign offices. Thus, transnational patents are patent applications with large patent families and therefore assumed to be patent applications with higher value. European applications are of special interest for European countries; international applications for Asian countries and the USA. In this way, transnational patents aim at the comparability of countries from different world regions. To understand the concept of transnational patents, it is helpful to look at European and international patents in more detail.

\section{European patents}

The European Patent Office (EPO) was established in 1978. Since then, it has been possible to examine a patent application centrally for a variety of member states of the European Patent Organisation. At present, this organisation has 38 members, the 28 EU member states and ten other countries including Switzerland and Turkey. If a patent is granted at the EPO, it has to be transferred to either all member countries or, in most cases, only to a set of designated states, where it becomes nationally valid provided the patent owner pays the relevant national fee. ${ }^{1}$ To summarise, at the EPO, the application and examination are centralised, but the final protection refers to selected countries and is national. Thus, the member countries recognize the grant at the EPO, but in the end the patents are registered nationally for getting validity.

With regard to family size, an EPO application means that, in addition to the first domestic application, the so-called priority application, an additional second application is associated with the invention. The family size is therefore two. Only after the EPO application is granted, it is transferred to other national offices and the family size then increases substantially after a delay of 3-5 years with reference to the application at the EPO. ${ }^{2}$

In every case, an application at the EPO always aims at several foreign applications. With the application at the EPO, the grant procedure at the EPO is mandatory. Transfers to national offices are not made, if.

- The patent is not granted at the EPO or

- The market expectations for the patent are dramatically reduced.

To conclude, a European application is a good indicator of patent value.

\section{International patents}

The Patent Cooperation Treaty (PCT) is an international patent law treaty concluded in 1970. It introduced the international application, which provides a unified international procedure for filing a patent. The application is made at a Receiving Office (RO) in one language. The next step is a search performed by an International Search Authority (ISA) resulting in a search report with a stated opinion regarding the patentability of the invention, which is the subject of the application. It is optionally followed by a preliminary examination performed by an International Preliminary Examining Authority (IPEA). The

\footnotetext{
${ }^{1}$ In most cases, the applicants select protection only in Germany, France and the UK.

${ }^{2}$ https://www.epo.org/service-support/faq/procedure-law.html.
} 
ROs, ISAs and IPEAs are selected existing patent offices, e.g. the United States Patent and Trademark Office (USPTO) or the European Patent Office (EPO) working on behalf of the World Intellectual Property Organisation (WIPO). In the final step, the inventor/applicant has to decide whether to pursue the application and in which countries to file for patent protection. The WIPO has 193 member states. Another option is to apply at the EPO as well, i.e. the so-called Euro-PCT application. The international application has a number of advantages. In particular:

- The applicant can submit valid applications designated for foreign countries shortly before the end of the priority year, as a translation into a foreign language and nominating the corresponding patent attorneys in the designated states are not necessary at this point in time, while these are required in the standard procedure without PCT.

- The applicant receives valid information on the patentability of the application through the reports of the ISAs and IPEAs before making a decision about cost-intensive applications in foreign countries.

- The international phase ends at 30 months from the priority date and therefore the applicant has to make the decision concerning applications in foreign countries much later than by the end of the priority year. $2 \frac{1 / 2}{2}$ years after the priority application, more information is available on whether the invention will be successful in the market and justify the cost of patent applications in foreign countries.

To conclude, PCT applications are generally made if the aim is to apply at several foreign patent offices. However, the search report and the preliminary examination offer the option to decide not to transfer the application to several national offices. Thus, an international application generally implies applications in several countries, but the share of not transferring the patent to several countries is higher than for an application at the EPO.

In the case of Chinese applicants, the Chinese Patent Office (China National Intellectual Property Administration, CNIPA) is the International Search Authority (ISA) and the International Preliminary Examining Authority (IPEA). Compared to purely national applications, the applicants receive early search and examination reports and the option of later applications in foreign countries. From December 2020, the EPO can also act as the ISA and IPEA for Chinese applicants. ${ }^{3}$.

\section{Family size of transnational patents}

To determine whether transnational patents really have larger families and whether there are balanced results for countries from different world regions, it is useful to examine the family size of transnational patents in more detail.

As transnational patents are based on European or international applications, the transfer to national offices and thus achieving larger families takes place after a certain delay. We use the count of publication numbers available in the STN version of the database World Patents Index (WPI) to analyse the size of patent families. This number is a bit higher than the size of patent families, as some countries assign different patent numbers to applications and grants, so the count of patent numbers is only a proxy.

$\overline{3}$ https://www.epo.org/news-events/press/releases/archive/2020/20201020_de.html 


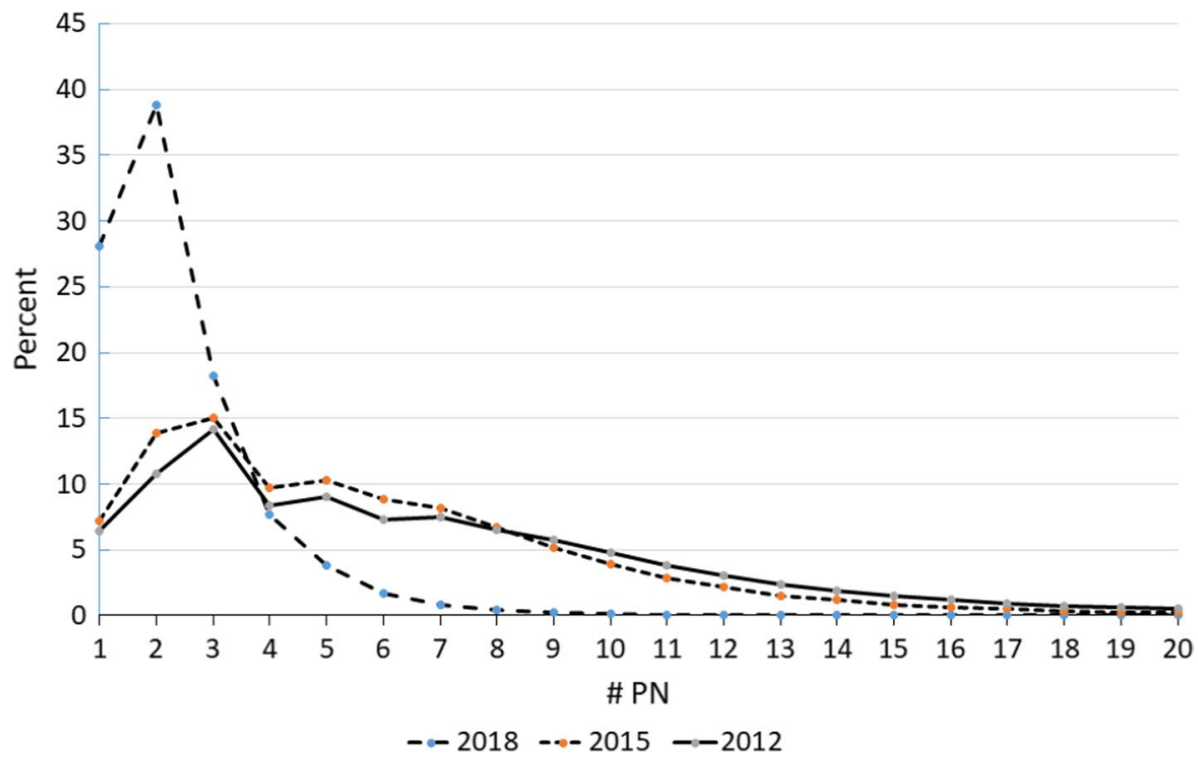

Fig. 1 Publication number counts of transnational patents for the priority years 2012, 2015 and 2018. Source WPI, own searches and calculations

Figure 1 shows the distribution of the publication number counts of transnational patents for different priority years. In 2018, the peak of publication number counts was at 2, which reflects an application in the home country and one additional European or international application. The relatively high share of count 1 refers to direct European or international applications without a domestic one. In 2015, the number of 2 counts was much lower and many applications have counts in the range of 4 to about 15 , reflecting the transfer of European or international applications to national patent offices. The distribution of counts for 2012 is similar to that of 2015, although the number of applications with counts in the range of 9 to about 17 was slightly higher. This is linked to a higher number of grants at the EPO and the related transfers to national offices. The average number of publication counts is 2.6 for $2018,5.7$ for 2015 and 6.7 for 2012 .

In the years, 2015 and 2012, the counts 1 and 2 stand for European or international applications which were never transferred to foreign national offices. If these are excluded, the average counts for 2015 and 2012 increase to 6.8 and 7.8. Looking at specific countries in 2015 and excluding counts 1 and 2, the averages are.

Total: 6.77

USA: 7.04

Germany: 6.74

China: 5.86

Japan: 7.21

South Korea: 6.61

The highest counts with 7.04 are in the USA and the lowest with 5.86 in China, but the counts are similar and at an elevated level for all countries. This confirms the basic assumptions that transnational patents have larger patent families and are suitable for comparing countries from different world regions. 


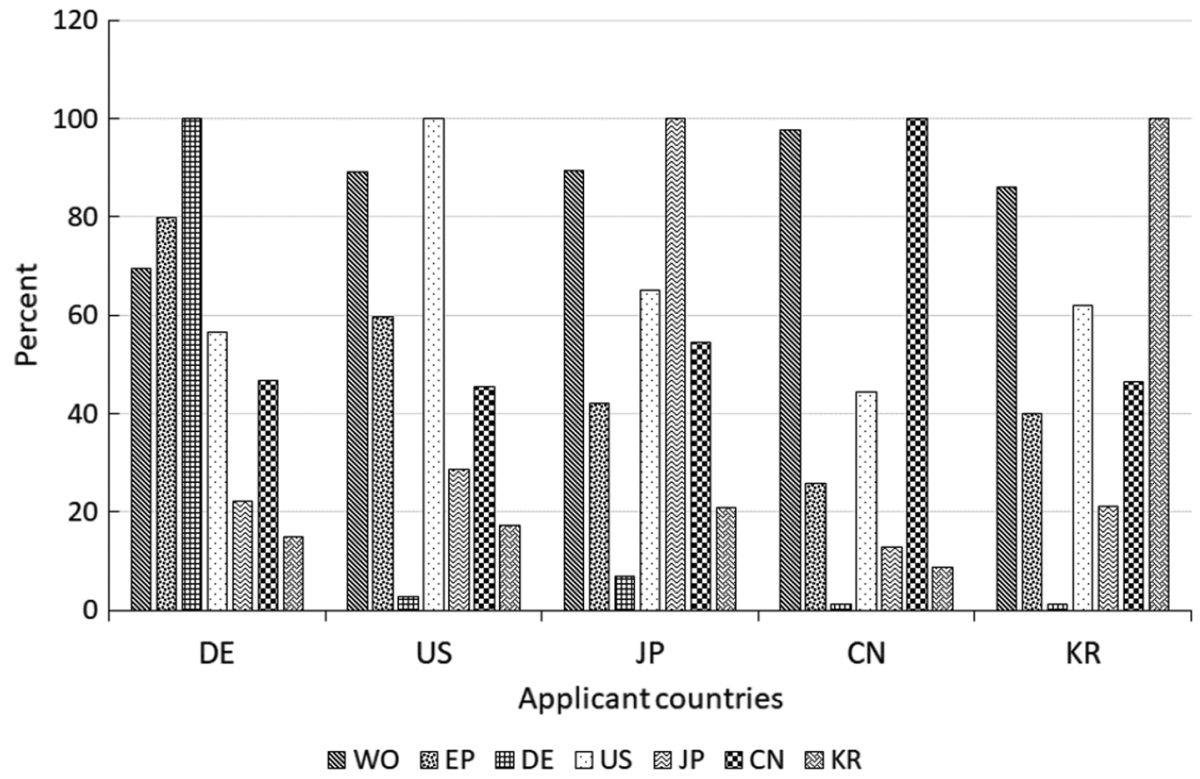

Fig. 2 Target patent offices of transnational patents for selected applicant countries in 2015. Source WPI, own searches and calculations

The level of count 3 indicates that European or international inventions are transferred to other national offices. Due to the different geopolitical situations, count 3 implies different additional applications for each country.

The transnational patents of Germany, which was chosen to represent a large European country, are 100\% in Fig. 2. 80\% of these are European applications and 70\% international applications, so there is a considerable overlap between European and international applications. In Germany, European and international applications already reach count 3 . The largest number of national applications is achieved in the USA with 57\%.

In the case of US applicants, international applications are at a level of $89 \%$. European applications are in third position with $60 \%$. As to applications at national patent offices, Chinese applications dominate with 55\%, followed by Japan and South Korea. The applications to Germany are quite low; obviously, the grant of European applications in 2015 is still limited. Most European applications have Germany as the destination country.

$90 \%$ of Japan's transnational patents are international applications, $65 \%$ are filed to the US Patent and Trademark Office (USPTO). Thus, the count 3 level is determined by the US applications. The share of European applications in Japan is $42 \%$ and thus lower than this share for US applicants. The share of applications in China is more important than Europe, with $55 \%$.

The Chinese focus on international applications. The count 3 level is determined by applications at the USPTO with $44 \%$. Thus, many international applications are not transferred to the USPTO. This confirms the observation of Frietsch and Kroll (2020) that Chinese PCT applications are transferred less often to national offices than PCT applications of other countries. The level of Chinese applications at the EPO is moderate with $26 \%$; the applications at the Japanese Patent Office are even lower with $13 \%$. 


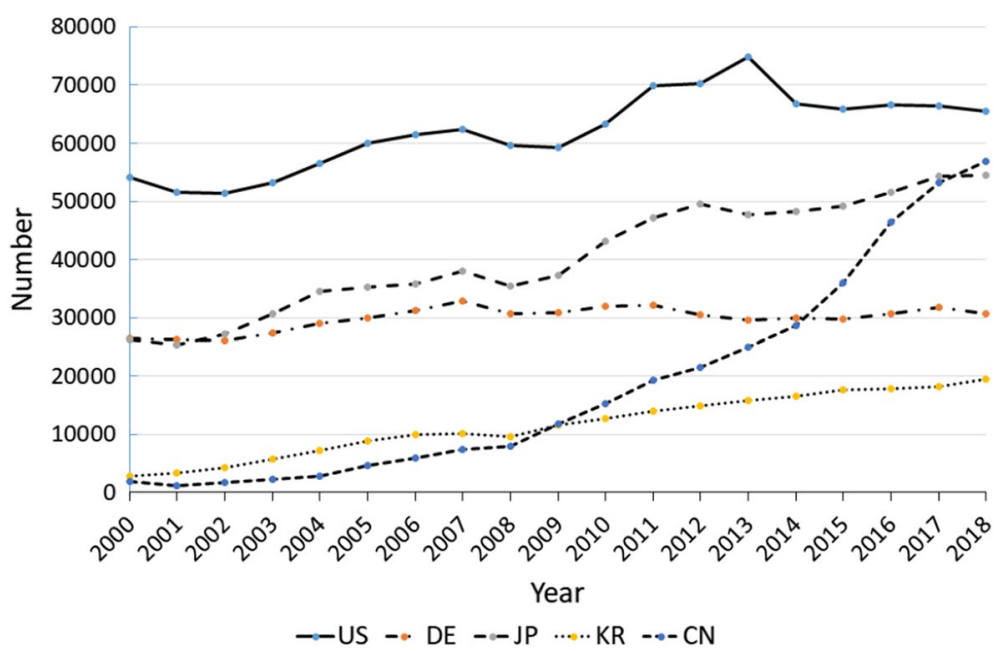

Fig. 3 Transnational patent applications for selected countries. Source WPI, own searches and calculations

South Korea shows a high level of international applications with $86 \%$. With $40 \%$, its level of European applications is comparable to Japan, and higher than China. With $62 \%$, the number of applications at the USPTO is again comparable to Japan. The USPTO applications determine the count 3 level of South Korea, which is distinctly higher than China. Thus, South Korea transfers a substantial number of PCT applications to national offices, and the limited transfer to national offices proves to be a specific Chinese phenomenon.

\section{The value of Chinese patents}

The analysis of the family size of transnational patents reveals that-compared to other countries - a significantly lower share of Chinese applications is transferred to national offices. This is strong evidence that the value of Chinese patents is lower than the value of patents from other countries.

The number of Chinese patent applications has been steadily increasing since 2000, and transnational patent statistics reveal that China has recently overtaken Japan and nearly drawn level with the USA (Fig. 3). These developments have triggered a broad debate about the value of Chinese patent applications.

Cheng and Drahos (2017) describe in detail that patent policy is a substantive part of China's innovation policy. Patent applications are stimulated by subsidies and pressure mechanisms at national and regional level, which are aimed at meeting the government's official targets. This finding is supported by Prud'homme (2015), who identified a patent quantity-at-any-cost strategy for the early years around 2000, supported by subsidies and pressure mechanisms, and an associated risk of low patent value.

The Chinese patent policy is derived from the communistic planning strategies of the Soviet Union on the one hand and the innovation strategy of Japan on the other hand, in which patent support was an important element. Maskus (1999) gives a detailed analysis of the link between patents and economic growth in Japan, and Xiao-qing (2001) shows how the Chinese patent policy refers directly to the Japanese one. This imitation of the Japanese 


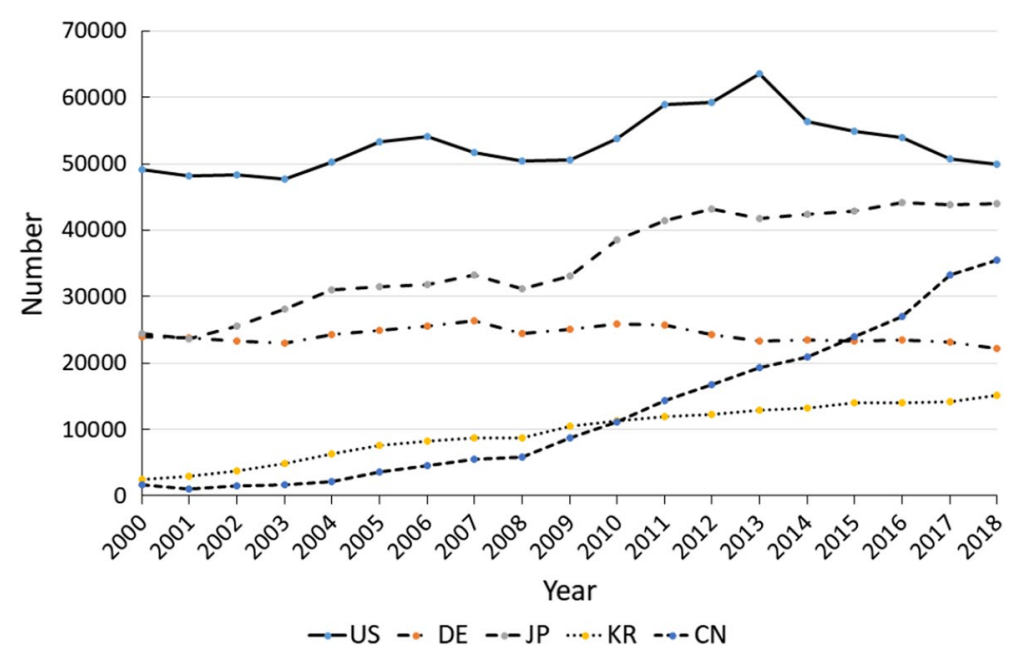

Fig. 4 Transnational patent application with counts of at least 3 for selected countries. Source WPI, own searches and calculations

innovation model by China, South Korea and many other Southeast Asian countries is discussed in many papers as the "flying geese" model (see, e.g. Kojimaa, 2000). South Korea, for instance, follows a similar way of stimulating patent applications as visible in the strong increase of patent activities shown in Fig. 3.

Dang and Motohashi (2015) examine the impact of the support policy of patents in China. They find a close correlation between the R\&D input and domestic patent applications, showing that the increase in Chinese patenting reflects an increase in research and development. However, the authors also state that the "patent subsidy programs increase patent counts more than 20\% (ibid. 137)". They also see the risk of a lower patent quality. This apprehension is confirmed by Xiaoning Long and Wang (2019), who find a negative impact of the patent promotion policies (PPPs) on the quality of domestic patent applications. This result is substantiated by Boeing and Mueller (2015) based on a different methodology. In particular, they analysed the impact of subsidies on PCT applications.

To summarize, various papers have described the patent promotion policies of the Chinese government and derived a negative impact on the value of domestic and foreign patent applications of Chinese applicants. With regard to PCT applications in particular, the patent promotion policies obviously aim at stimulating innovation, but also at raising the prestige of Chinese technology.

The above assumption that the lower transfer of Chinese transnational patents to foreign countries reflects a lower patent value is supported by the relevant literature on the value of Chinese patents. If only the transnational patents with counts of at least 3 are considered, the time series of Fig. 3 become the graph shown in Fig. 4.

In Fig. 4, the data for all years are based on real searches. The data for applications transferred to foreign countries are incomplete only for the year 2018. Therefore, the transfer rates of 2017 are used to calculate the data for 2018. Based on this different counting, Chinese applications also increase, but at a lower level compared to the level of other countries in Fig. 3, and do not reach the level of Japan. The relative reduction differs by country and is between 10 and $15 \%$. 
Kashcheeva et al. (2014) examine the technological orientation of Chinese PCT applications in more detail. They identify a focus on technologies such as digital communication, telecommunications, computer technology, audio-visual technology, optics, IT methods, control technology and biotechnology. Eberhardt et al. (2011) find that Chinese "firms that actively patent abroad are generally larger, younger, and more export-oriented than those that patent solely in the domestic market (ibid: 1)".

Looking at the technology orientation of domestic applications, we find almost the opposite profile. According to our own analyses, the focus here is on food chemistry, machine tools, civil engineering, chemical engineering, handling, special machines or furniture and other consumer goods. Thus, the orientation is towards private consumption such as nutrition, clothing, habitation etc. It is therefore important to differentiate between the value of domestic and of foreign patent applications.

\section{China's transition from export-driven to domestic-based growth}

Since the reforms and opening-up in the late 1970s, China has undergone drastic economic growth, demonstrated by its average annual growth rate of $8.7 \%$ from 1980 to 2015 . Achieving this was based on a sequence of market-oriented institutional reforms, including openness to international trade and direct investment (Wu et al., 2018). However, the influence of the state has remained strong (Bertoldi et al., 2016). The main drivers of economic growth in this period were the rapid increase in exports of consumer goods and very high investments in industry, infrastructure and real estate. Opening the country up to foreign direct investment in particular contributed to a large number of new factories that established China's new role as the "World Factory of Manufacturing" (Wu et al., 2018).

The country's rapid export-oriented industrialisation (Aiginger and Rodik, 2020) also benefitted from an ample labour supply linked to China's fast-rising population and the absorption of workers from the countryside into modern manufacturing sectors ("demographic dividend", Cai, 2020). This combination of productivity gains and factor accumulation enabled a rapid convergence and catch-up to higher income levels (Dieppe et al., 2018).

In the 2010s, however, the Chinese growth model came under increasing pressure due to rising labour costs and weaker external demand. Although the People's Republic remains one of the leading export nations and continues to dominate entire sectors such as the electronics industry, it has relinquished some of its dominance in labour-intensive export sectors to other Southeast Asian countries. Chinese wages are now higher than a majority of non-OECD economies. In addition, since 2012, the rapid aging of China's population caused by the one-child policy implies a shrinking labour force and an old-age dependency ratio that is set to double in the next two decades (Bertoldi \& Melander, 2015).

Both theoretical and empirical research suggest the rapid growth that many emerging economies experience on the back of low-cost labour and easy technology adaptation is rarely sustainable. Most of these countries have found themselves stuck in the middleincome trap and unable to graduate to the status of advanced economies (Im \& Rosenblatt, 2013; IMF, 2013). 


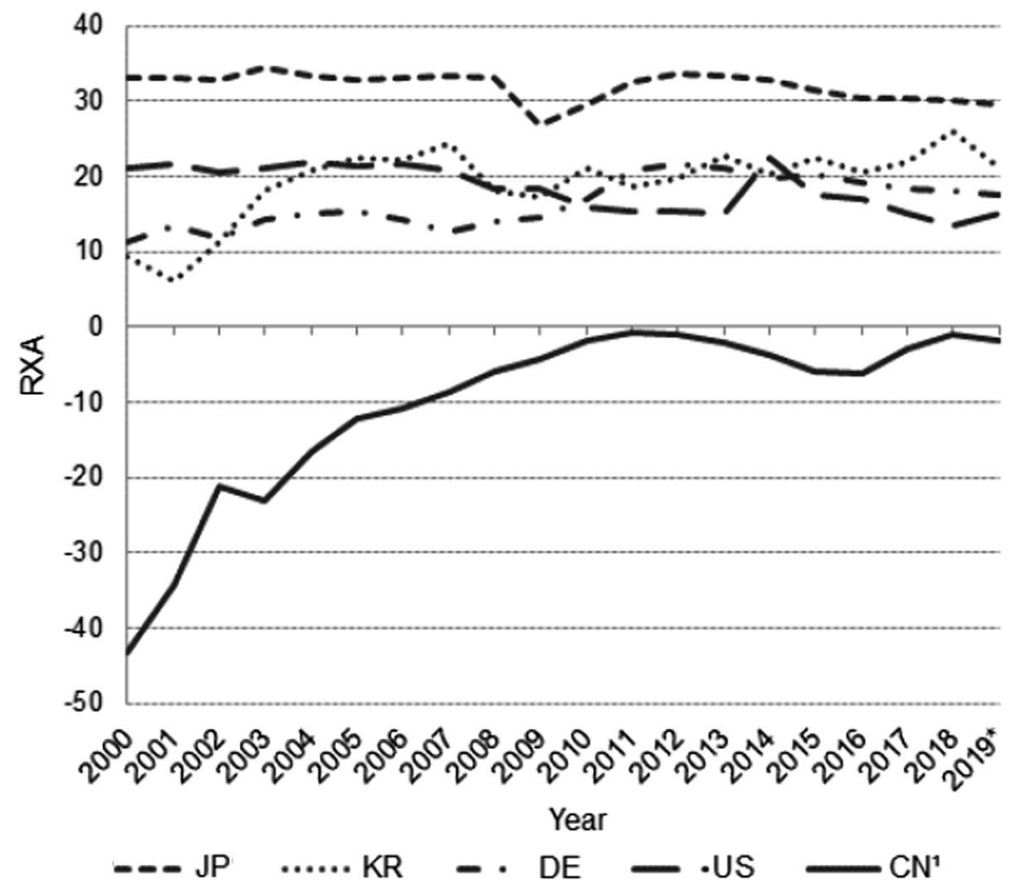

Fig. 5 Export specialization (RXA) in research-intensive goods for selected countries 2000-2019. ${ }^{1}$ China including Hong Kong, *world exports 2019 estimated. Source UN Comtrade database, own searches and calculations

To avoid this problem, the Chinese government has been propagating a "New Normal" since 2014. This represents a transition phase with only medium-high GDP growth of 6-7\% associated with the shift from the former export-led growth model to a domestic- and consumption-based economic model. ${ }^{4}$ This change in strategy is reflected in China's Five-Year-Plans as well as the "Made in China 2025" strategy, which was published in 2015. Main targets include strengthening the domestic innovation system and the technology-driven modernization of the economy, with particular focus on key technologies, the expansion of the service economy, and sustainability.

To some extent, China is following the blueprint of other East Asian economies (e.g. Japan, South Korea) in breaking through the ceiling of low-tech and labour-intensive manufacturing that restricts the growth of developing and emerging economies (see also chapter 5 with respect to patents). This development model is characterized by industrial policies aimed at strategic sectors and by a strong government that effectively aligns state-owned and private business interests with national targets. Using this template, China hopes to overcome the middle-income trap and reduce its reliance on foreign technology, export demand as well as mitigate increasing trade conflicts (Zenglein and Holzmann, 2019).

\footnotetext{
4 Already in December 2004, China 's top political leadership agreed to fundamentally alter the country 's development strategy by transitioning to a growth path that relied more on expanding domestic consumption (Lardy 2007). However, this remained a statement of intent only for quite some time.
} 
This change in development strategy is also reflected in China's export performance. Here, the focus is on research-intensive goods (Fig. 5). In terms of sales, these are characterized by particularly high R\&D expenditures and correspondingly high patent activities (Frietsch et al., 2012; Kashcheeva et al., 2014). These goods include pharmaceuticals, most electronic products, telecommunications, computers, machinery, aircraft, motor vehicles, and several chemical products and electrical products (Gehrke et al., 2013). The share of electronic consumer goods in Chinese exports is comparatively high.

The indicator considered is not the absolute export share, but the export specialization (RXA).

$$
\left.\mathrm{RXA}_{\mathrm{kj}}=100 *\left(\ln \left[\left(A_{\mathrm{kj}} / \sum_{j} A_{\mathrm{kj}}\right) /\left(\sum k A_{\mathrm{kj}} / \sum_{\mathrm{kj}} A_{\mathrm{kj}}\right)\right]\right)\right)
$$

The RXA compares the export $(A)$ share of a certain product group $\mathrm{j}$ in all manufacturing exports in a given country $k$ with the global export shares of these product groups in the global exports in manufacturing goods. Thus, a positive RXA value indicates that the country has comparatively higher export market shares in this specific product group than it does in total manufacturing goods.

Figure 5 illustrates the significant catching-up China achieved until 2011 and the clear export emphasis on research-intensive goods. The stagnation since then can also be interpreted as an indication of a stronger domestic market orientation, especially in innovative goods, which are expected to drive China's technological development. This could be another explanation for why many international patent applications in China are not actually transferred to other foreign offices, but remain purely domestic.

\section{Quest for appropriate patent count}

The reduced transfer of Chinese PCT applications to foreign offices, the discussion about the value of Chinese patents and the stronger domestic orientation of China are strong indications that the real transnational patents with consideration of the reduced transfer is more appropriate than nominal transnational patents where only the formal criteria of European or PCT application is fulfilled. However, it is possible that the fact of a PCT application indicates a higher value even, if the application remains purely domestic later on. Therefore it is necessary to pursue this question in more detail.

A possible option is to relate the number of transnational patents to the Business Enterprise Research and Development Expenditure (BERD). The relation of the total national (domestic) patents to the total national BERD shows that, e. g., the level for China is about 13 times higher than that of the USA. When the relation of the total national transnational patents to the total national BERD is calculated, leads to a relation of China to the USA of 0.76 . Thus, transnational patents imply a much more realistic picture, but it is not clear, whether nominal or real transnational patents are more appropriate, as for each country, the relation between patents and BERD is specific and different to the level of other countries. The responsiveness of China to BERD input is distinctly lower than for Germany, the USA, Japan or South Korea (Cerulli, 2014), but the "correct" level is vague. Furthermore, the relation of BERD and patents differs by technology. Therefore, a more disaggregate analysis obviously leads to more appropriate results, whereas the analysis at the aggregate level implies a mixture of different technology levels. 


\section{Analysis by technology for Chinese transnational patents and exports}

The findings of the former chapter suggest to analyse the patenting behaviour of countries, in particular the reduced transfer of Chinese PCT applications, by technology to achieve a better understanding of the underlying structures.

To analyse the transfer of Chinese transnational patents by technology, the nominal number of transnational applications by technology were recorded as well as the number of real transnational applications with a count of at least 3. Nominal transnational patents fulfil the formal criterion of international or European applications; real transnational patents are applications with larger families and thus applications with higher value-defined as transnational patents with counts of at least 3 . This results in a transfer rate of $79 \%$ for all nominal applications of all countries. For China, this rate is only $66 \%$.

In the next step, the share of China's nominal technology-specific transnational applications in all applications in the respective technology is calculated, e.g. $11.2 \%$ of all applications in electrical engineering come from Chinese applicants. The same share is then calculated for real transnational applications, which is $9.4 \%$ in this example. If the transfer rate to foreign countries were the same for China as for the rest of the applicant countries, the share in this field would be the same. The lower share indicates a lower transfer rate for China than for other countries.

In Fig. 6, the share of China in all technologies combined serves as a reference for the engagement of China in the specific technology, e.g. for electrical engineering it is $11.2 \%$, while the average share for all technologies is $14.1 \%$. Thus, the Chinese engagement in electrical engineering is below average.

In addition, Fig. 6 shows the difference of the real and nominal shares of technologies for Chinese transnational patents (rnDiff) calculated as

$$
\mathrm{rnDiff}=(\mathrm{rShare} / \mathrm{nShare}-1)
$$

wherein rShare is the share of China within a technology for all real transnational patents in this technology and nShare the Chinese share within nominal transnational patents. For electrical engineering, the nominal share is $11.2 \%$, the real share $9.4 \%$, the relation of the real to the nominal share is 0.84 . The value minus 1 shows that the real value is about $16 \%$ lower than the nominal one, that there is a negative difference of $16 \%$. In optics, the rShare and nShare is equal, leading to $\mathrm{rnDiff}=0$.

The difference between real and nominal varies considerably by technology. It is large for fields with high specialisation in PCT applications and thus in transnational patents such as digital communication, telecommunications, computer technology, IT methods or control technology. Medium differences can be found for technologies with high specialisation in domestic applications such as food chemistry, machine tools, civil engineering, chemical engineering, handling or special machines. In some technologies, the difference is zero or even positive, for instance, in semiconductors, optics, analysis of biological material, organic chemistry or micro- and nanotechnology.

As the technologies with high specialisation in transnational patents have a distinct orientation towards exports, the main reason for the large differences is a lower value of the patents due to the support of PCT patenting by the government. These patents are often not transferred to foreign countries. The reasons for the medium differences in technologies with high specialisation in domestic applications are the interest in an early search and examination report and the support by the government, but less interest 
Electr. energy Audio-vis. techn.

Telecommunic. Digital communic.

Basic communic. Computers IT methods Semiconductors Optics Measurement Anal. of biol. mat. Control

Med. technology Organic chemistry Biotechnology Pharmacy Polymers

Food chemistry Basic mat. chem. Mats, metallurgy Surface techn. Mikro-, nano-techn. Chem. engineering Environm. techn. Handling, robots Machine tools Additive manuf. Engines, turbines Text./paper-mach. Other spec. mach. Thermal processes Mechanical elemts Transport, vehicles Furniture, games Other consum. gds Civil engineering

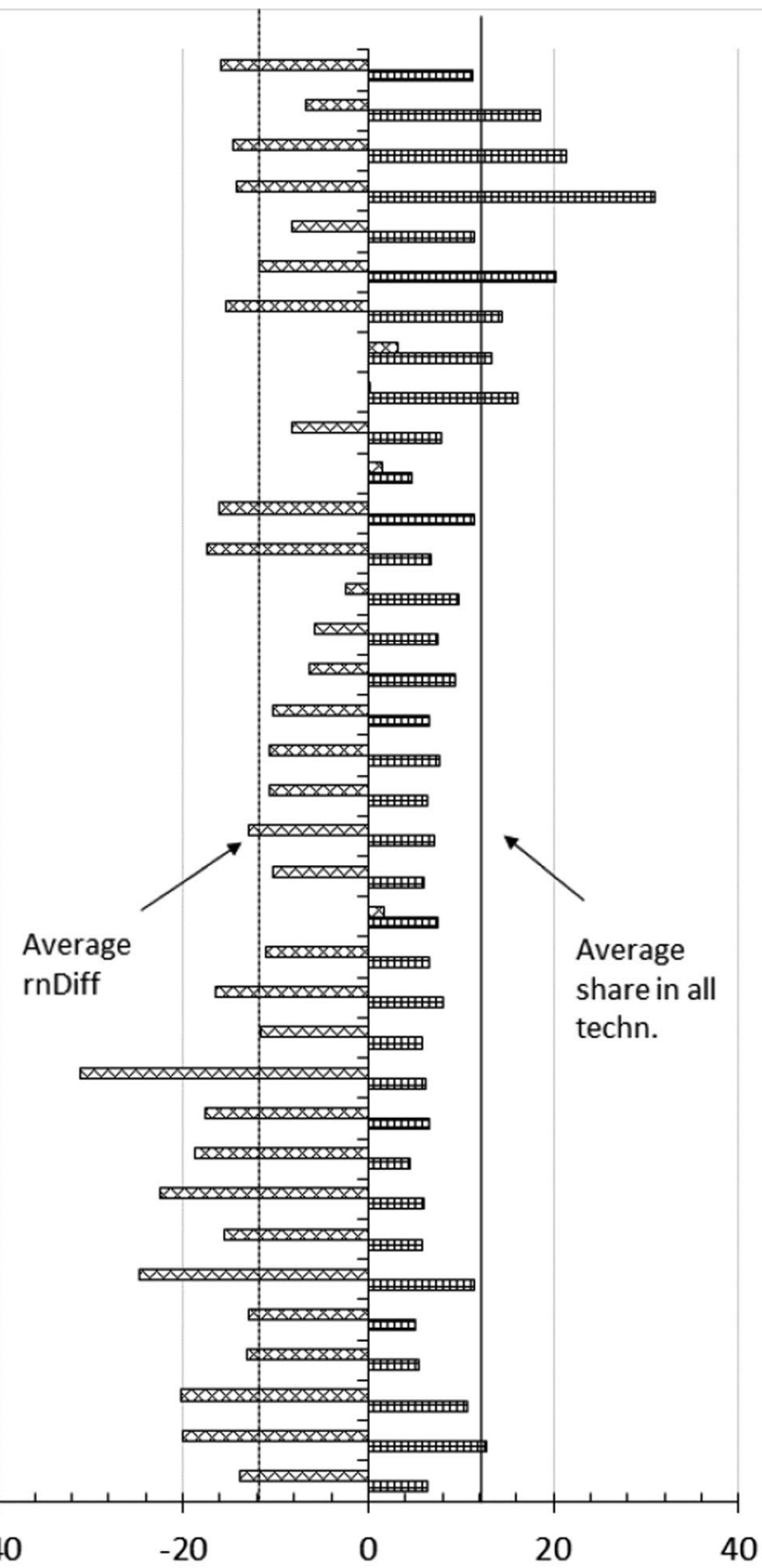

rnDiff (\%) 囵 Share in all techn. (\%)

Fig. 6 Shares of technologies and differences of real and nominal values for Chinese transnational applications in 2015. Source WPI, own searches and calculations 
Fig. 7 Comparison of patent and export specialisation (RPA, RXA) in China for selected goods in 2015. Sources WPI, UN Comtrade database, own searches and calculations

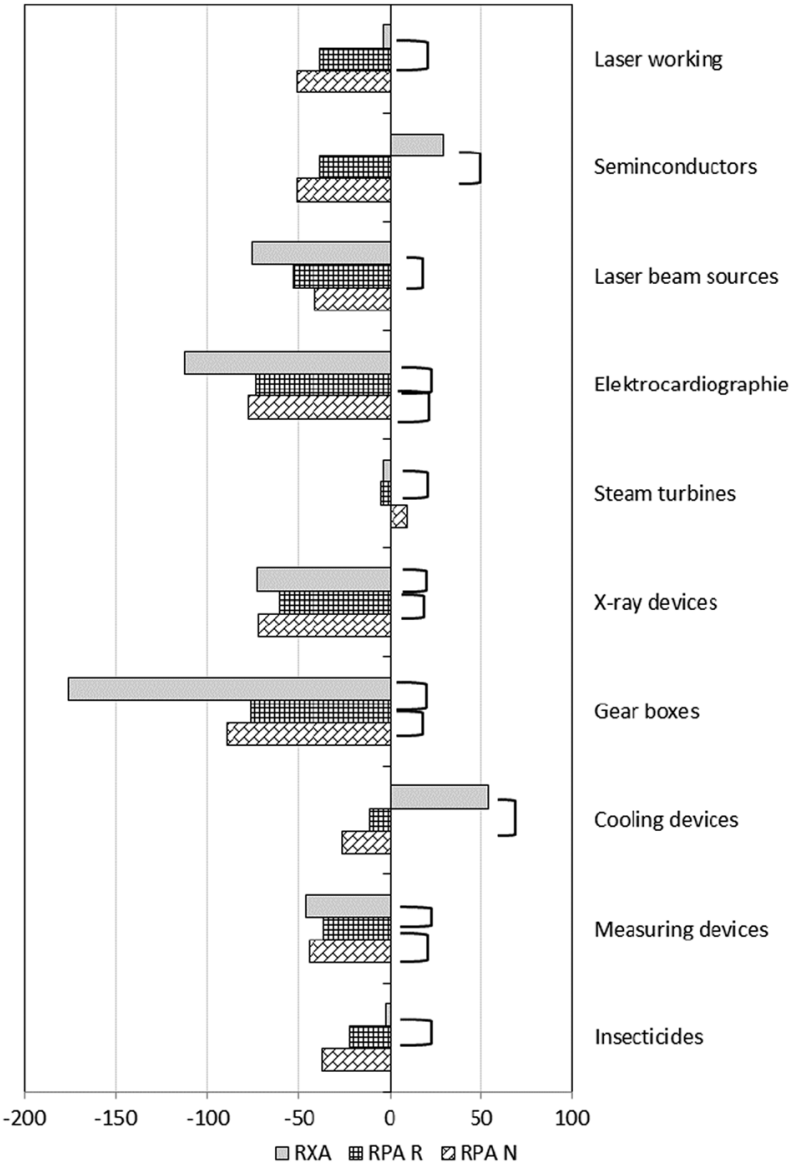

in exports. In the case of low differences, there is obviously a strategic interest in these technologies. In these technologies, all PCT applications really aim at the protection of exports, thus being transferred to foreign countries.

It is difficult to analyse the link between patents and exports. The best approach is to compare the specialisation in patents with that of exports analogous to the Revealed Export Advantage (RXA, see chapter 6 above). The Revealed Patent Advantage (RPA) is calculated as follows.

$$
\left.\mathrm{RPA}_{\mathrm{kj}}=100 *\left(\ln \left[\left(\mathrm{P}_{\mathrm{kj}} / \sum_{j} \mathrm{P}_{\mathrm{kj}}\right) /\left(\sum k \mathrm{P}_{\mathrm{kj}} / \sum_{\mathrm{kj}} \mathrm{P}_{\mathrm{kj}}\right)\right]\right)\right)
$$

Therein, the index $\mathrm{k}$ stands for the country and the index $\mathrm{j}$ for the technology. Positive values represent an above-average specialisation, negative ones below-average specialisation; the neutral value is 0 . 
To establish a link between patents and exports, it is necessary to match the codes of the Standard International Trade Classification (SITC) with the codes of the International Patent Classification (IPC). Such a match is difficult, as the SITC is a classification of goods and the IPC a classification of technologies. To achieve a sufficient correlation, the goods must be research-intensive, ${ }^{5}$ so that the technological quality has an impact on the performance in foreign trade.

We checked a variety of different goods in terms of SITC, defined related IPCs and calculated the values of RXA and nominal and real RPA based on nominal and real transnational patents. In many cases, the value of the real RPA is lower than that of the nominal one, in some cases, the nominal and real values are equivalent, in some cases, the nominal values are even higher than the real ones. In most cases, the match of the real values of the RPA with the RXA is better than that with the nominal values.

In Fig. 7, some cases of RXA, RPA $N$ and RPA $R$ for selected goods are shown as examples for a good match between RXA and RPA $R$. These goods are linked to technologies which are on a lower level of aggregation than the broader technology fields of Fig. 6. For instance, steam turbines are part of the field "Engines, turbines" in Fig. 6 and the real value is lower than the nominal value in the field and the specific technology. Furthermore, the correlation between RXA and RPA $R$ proves to be better than that between RXA and RPA $N$. All in all, the better correlation between the values of RXA and RPA $R$ is not allembracing, as for the performance of foreign trade other aspects than technology have an impact, in particular the level of costs. But in most cases, the correlation between RXA and RPA $R$ is better.

To conclude, on this fine level of disaggregation which is again finer than the disaggregation of BERD, the higher validity of real transnational patents compared to nominal ones can be shown by a better match between patent and export specialisation. Both indicators reflect international technological competitiveness,

\section{Conclusions}

Transnational patents prove to be an appropriate tool to compare the patent activities of different countries in specific fields of technology. The concept behind transnational patents is to compare patent applications with high patent transfers to foreign countries, i.e. patents with large families, as these represent patent applications with high value. However, not all transnational patents are actually transferred to foreign countries if the international search and examination prove less favourable. This observation applies to all applicant countries, but the transfer rate is significantly lower in China than in other countries. This lower transfer rate can be explained by the lower patent value, which in turn is associated with the subsidies and political pressure from the Chinese government used to support patents, in particular PCT applications. Another reason is the decelerated export orientation in China in favour of a stronger focus on the domestic economy particularly with respect to $R \& D$ intensive goods. The lower transfer rates do not apply to all technologies in the same way. There are fields with standard transfer rates and others with low or very low transfer rates. The reasons for lower transfer rates-lower export orientation or lower value-also differ by technology. To summarize, nominal transnational patents are a useful tool for standard country comparisons on an aggregate level. For the analysis of specific technologies, real transnational patents are more appropriate.

\footnotetext{
${ }^{5}$ For a definition of research-intensive goods, see Gehrke et al. (2013).
} 
Open Access This article is licensed under a Creative Commons Attribution 4.0 International License, which permits use, sharing, adaptation, distribution and reproduction in any medium or format, as long as you give appropriate credit to the original author(s) and the source, provide a link to the Creative Commons licence, and indicate if changes were made. The images or other third party material in this article are included in the article's Creative Commons licence, unless indicated otherwise in a credit line to the material. If material is not included in the article's Creative Commons licence and your intended use is not permitted by statutory regulation or exceeds the permitted use, you will need to obtain permission directly from the copyright holder. To view a copy of this licence, visit http://creativecommons.org/licenses/by/4.0/.

\section{References}

Aiginger, K., \& Rodrik, D. (2020). Rebirth of industrial policy and an agenda for the twenty-first century. Journal of Industry, Competition and Trade. https://doi.org/10.1007/s10842-019-00322-3

Beckert, B., Buschak, D., Graf, B., Hägele, M., Jäger, A., Moll, C., Schmoch, U., \& Wydra, S. (2016). Automatisierung und Robotik-Systeme, Studien zum deutschen Innovationssystem Nr. 11-2016, Berlin: EFI.

Bertoldi, M., Eriksgard Melander, A., \& Weiss, P. (2016). Can economic transitions be planned? China and the 13th Five-Year-Plan. European Economy Economic Briefs No. 017, September 2016.

Bertoldi, M., \& Melander, A. (2015). China's reforms: Time to walk the talk, ECFIN Economic Briefs No. 41. April 2015. Brussels.

Boeing, P., \& Mueller, E. (2015). Measuring patent quality in international comparison: Index development and application to China, ZEW Discussion Papers, No. 15-051, Mannheim, ZEW.

Cai, F. (2020). The second demographic dividend as a driver of China's growth. China and World Economy, 28(5), 26-44. https://doi.org/10.1111/cwe.12350

Cheng, W., \& Drahos, P. (2017). How China built the world's biggest patent office-The pressure driving mechanism. IIC - International Review of Intellectual Property and Competition Law, 49, 5-40. https://doi.org/10.1007/s40319-017-0655-1

Cerulli, G. (2014). The impact of technological capabilities on invention: An investigation based on country responsiveness scores. World Development, 59, 147-165. https://doi.org/10.1016/j.world dev.2014.01.019

Dang, J., \& Motohashi, K. (2015). Patent statistics: A good indicator for innovation in China? Patent subsidy program impacts on patent quality. China Economic Review, 35, 137-155. https://doi.org/ 10.1016/j.chieco.2015.03.012

Dechezleprêtre, A., Ménière, Y., \& Mohnen, M. (2017). International patent families: From application strategies to statistical indicators. Scientometrics, 111(2), 793-828. https://doi.org/10.1007/ s11192-017-2311-4

De Rassenfosse, G., Dernis, H., Guellec, D., Picci, L., Pottelsberghe, V., \& de la Potterie, B. (2013). The worldwide count of priority patents: A new indicator of inventive activity. Research Policy, 42(3), 720-737. https://doi.org/10.1016/j.respol.2012.11.002

Dieppe, A., Gilhooly, R., Han, J., Korhonen, I., \& Lodge, D. (ed.) (2018). The transitions of China to sustainable growth-Implications for the global economy and the euro area. European Central Bank, Occasional Paper Series, No. 206, January 2018.

Döscher, H., \& Reiss, T. (2021). Graphene roadmap briefs (No. 1): innovation interfaces of the Graphene Flagship. 2D Materials. https://doi.org/10.1088/2053-1583/abddcc

Eberhardt, M., Helmers, C., \& Yu, Z. (2011). Is the Dragon Learning to Fly? An Analysis of the Chinese Patent Explosion. The University of Nottingham Research Paper No. 2011/16, Available at SSRN: https://ssrn.com/abstract $=1965963$

Frietsch, R., \& Kroll, H. (2020). China's foreign technology market perspectives, In. M. Dowling (ed.), Deutsch-chinesische Innovationspartnerschaft:Rahmenbedingungen, Chancen und Herausforderungen (pp. 365-375). Metropolis.

Frietsch, R., Neuhäusler, P., \& Rothengatter, O. (2012). Patent applications-Structures, trends and recent developments, Studien zum deutschen Innovationssystem Nr. 8-2012, Berlin, EFI.

Frietsch, R., \& Schmoch, U. (2010). Transnational patents and international markets. Scientometrics, 85, 185-200. https://doi.org/10.1007/s11192-009-0082-2

Gehrke, B., Frietsch, R., Neuhäusler, P., \& Rammer, C. (2013). Re-definition of research-intensive industries and goods - NIW/ISI/ZEW-Lists 2012, Studien zum deutschen Innovationssystem 8-2013, Berlin, EFI. https://www.e-fi.de/fileadmin/Innovationsstudien_2013/StuDIS_08-2013NIW_ISI_ZEW_engl.pdf. 
Griliches, Z. (1990). Patent statistics as economic indicators: A survey. Journal of Economic Literature, 28, 1661-1707.

Grupp, H., Münt, G., \& Schmoch, U. (1996). Assessing different types of patent data for describing high technology export performance, In. OECD (Ed.), Innovation, patents and technological strategies: Proceedings of a Workshop held at OECD Headquarters in Paris (pp. 271-287), 8-9 December 1994. Paris: OECD.

Haščič, I., Silva, J., Johnstone, N. (2015). The use of patent statistics for international comparisons and analysis of narrow technological fields, OECD Science, Technology and Industry Working Papers 2015/05, Paris: OECD.

Harhoff, D., Scherer, F. M., \& Vopel, K. (2003). Citations, family size, opposition and the value of patent rights. Research Policy, 32(8), 1343-1363. https://doi.org/10.1016/S0048-7333(02)00124-5

Hinze, S., \& Schmoch, U. (2004). Opening the black box. Analytical approaches and their impact on the outcome of statistical patent analyses. In W. Glänzel, H. Moed, \& U. Schmoch (Eds.), Handbook of quantitative science and technology research. The Use of publication and patent statistics in studies on $R \& D$ systems. Kluwer Academic Publishers.

Im, F. G., \& Rosenblatt D. (2013). Middle-Income Traps, a conceptual and empirical survey, Policy Research Working Paper 6594, Washington D.C., World Bank.

IMF. (2013). Growth slowdowns and the middle-income trap, IMF Working Paper 13/71, International Monetary Fund, Washington D.C., March.

Kashcheeva, M., Wunsch-Vincent, S., \& Zhou, H. (2014). International Patenting Strategies of Chinese Residents: An analysis of foreign-oriented patent families, Economic Research Working Papers No. 20, Geneva: WIPO.

Kojimaa, K. (2000). The "flying geese" model of Asian economic development: Origin, theoretical extensions, and regional policy implications. Journal of Asian Economics, 11(4), 375-401. https://doi.org/ 10.1016/S1049-0078(00)00067-1

Maskus, K. E., \& McDaniel, C. (1999). Impacts of the Japanese patent system on productivity growth. Japan and the World Economy, 11(4), 557-574. https://doi.org/10.1016/S0922-1425(99)00012-2

OECD. (2015). World corporate top R\&D investors: Innovation and IP bundles. OECD.

Pavitt, K. (1985). Patent statistics as indicators of innovative activities: Possibilities and problems. Scientometrics, 7, 77-99. https://doi.org/10.1007/bf02020142

Prud'homme, D. (2015). China's shifting patent landscape and state-led patenting strategy. Journal of Intellectual Property Law and practice, 10(8), 619-625. https://doi.org/10.1093/jiplp/jpw004

Schmoch, U., Grupp, H., Mannsbart, W., \& Schwitalla, B. (1988). Technikprognosen mit Patentindikatoren. Zur Einschätzung zukünftiger industrieller Entwicklungen bei Industrierobotern, Lasern, Solargeneratoren und immobilisierten Enzymen. Verlag TÜV Rheinland.

Schmoch, U., \& Khan, M. (2019). Methodological challenges for creating accurate patent indicators. In W. Glänzel, H. F. Moed, U. Schmoch, \& M. Thelwall (Eds.), Springer handbook of science and technology indicators. Springer.

WIPO (2019). World intellectual property indicators 2019, the geography of innovation, local hotspots, global networks. Geneva: WIPO.

Wu, J., Wei, Y. D., Li, Q., \& Yuan, F. (2018). Economic transition and changing location of manufacturing industry in China: A study of the Yangtze River Delta. Sustainability, 10, 2624. https://doi.org/10. 3390/su10082624

Xiaoning Long, C., \& Wang, J. (2019). China's patent promotion policies and its quality implications. Science and Public Policy, 46(1), 91-104. https://doi.org/10.1093/scipol/scy040

Xiao-qing, F. (2001). The patent strategy of Japanese enterprises and its inspiration to our country. Journal of Beijing University of Aeronautics and Astronautics.

Zenglein, M. J., \& Holzmann, A. (2019). Evolving made in China 2025. China's industrial policy in the quest for global tech leadership, Merics Papers on China No. 8, July 2019, Mercator Institut für China Studies, Berlin. 